\title{
Pengaruh Keselamatan dan Kesehatan Kerja Terhadap Produktivitas Kerja Karyawan
}

\author{
M. Fajar Nugroho ${ }^{1}$, Rakhmat Haryono ${ }^{2}$ \\ Pengajar Politeknik Pajajaran Insan Cinta Bangsa Bandung \\ fajar.nugroho@poljan.ac.id 1 \\ rakhmat.haryono@poljan.ac.id ${ }^{2}$
}

\begin{abstract}
ABSTRAK
Tujuan penelitian adalah untuk mengetahui dan menganalisis bagaimana pengaruh keselamatan dan kesehatan kerja terhadap produktivitas kerja karyawan di salah satu rumah sakit swasta di kota Bandung, baik secara parsial maupun simultan. Jenis penelitian ini adalah penelitian kuantitatif dengan metode penelitian survey deskriptif dan metode verifikatif. Variabel independen dalam penelitian ini adalah keselamatan kerja $\left(\mathrm{X}_{1}\right)$ dan kesehatan kerja $\left(\mathrm{X}_{2}\right)$, sedangkan variabel dependennya adalah produktivitas kerja (Y). Responden yang digunakan adalah karyawan yang bekerja di salah satu rumah sakit swasta di kota Bandung dengan jumlah sampel sebanyak 280 orang yang dipilih dengan menggunakan teknik simple random sampling dengan bantuan rumus Isaac dan Michael. Data yang digunakan adalah data primer dan sekunder. Instrumen utama penelitian adalah kuesioner yang diuji validitasnya menggunakan Product Moment Pearson dan realibilitasnya dengan menggunakan metode $\alpha$-Cronbach. Untuk menguji hipotesis digunakan statistik yaitu analisis jalur (path analysis). Dari hasil penelitian diperoleh hasil bahwa secara parsial keselamatan kerja dan kesehatan kerja berpengaruh terhadap produktivitas kerja karyawan baik secara simultan maupun parsial. Secara parsial keselamatan kerja memberikan pengaruh yang lebih dominan terhadap produktivitas kerja dibandingkan dengan kesehatan kerja.
\end{abstract}

Kata Kunci : Keselamatan kerja, Kesehatan Kerja, Produktivitas Kerja.

\begin{abstract}
The purpose of this research is to investigate and analyze how occupational safety, occupational health and work productivity, and the influence of occupational health and safety to work productivity in one the private hospitals in Bandung, either simultaneously or partially. Type of this research is quantitative research and the method used in this research is survey descriptive and verification method. Independent variables in this research are Occupational Safety (X1) and Occupational Health (X2), and the dependent variable is labour productivity $(Y)$. Respondent who used were employees in one of the private hospitals in Bandung with the number of samples were 280 people selected by simple random sampling techniques with the help of Isaac and Michael tabel. The data used are primary and secondary data. The main instrument of thi research is the questionnaire. To test the validity instrument is using Product Moment Pearson and the realibility using $\alpha$-Cronbach. The statistical hypothesis is using path analysis. The research result shows that the occupational safety and health partially and simultaneously have an effect on work productivity. Partially, occupational safety have a more dominant effect on work productivity compared with occupational health.
\end{abstract}

Keywords: Occupational safety, Occupational Health and Work Productivity.

\section{PENDAHULUAN}

Saat ini sebuah perusahaan dituntut untuk mampu menyesuaikan diri dengan tuntutan perubahan yang sangat cepat terjadi. Salah satu perubahan tersebut adalah teknologi yang begitu banyak hadir menyesuaikan diri dengan kebutuhan perusahaan. Akan tetapi peran teknologi tersebut ternyata menuntut sumber daya manusia yang memiliki mutu dan kompetensi. Hal tersebut bertujuan untuk lebih meningkatkan efisiensi serta produktivitas perusahaan. Merujuk dari hal tersebut, selain teknologi peran sumber daya manusia sangat dibutuhkan sebagai ujung tombak bagi kehidupan perusahaan, karena dari semua faktor produksi, manusia merupakan faktor yang paling utama berperan dalam suatu perusahaan. Selain daripada itu, arti pentingnya manusia di sebuah perusahaan juga dianggap sebagai "alat produksi" ditinjau dari aspek tenaga, keluaran, ketahanan fisik dan mental.

Secara umum penilaian produktivitas kerja telah banyak dilakukan oleh perusahaan-perusahaan, karena penilaian produktivitas kerja mempunyai 
manfaat yang sangat banyak bagi kebijakan manajemen dalam kaitannya dengan sumber daya manusia. Sedangkan tingginya tingkat produktivitas tersebut dapat ditingkatkan melalui peningkatan kualitas dan kuantitas kerja. Era industrialisasi yang ditandai oleh pertumbuhan dan perkembangan sektor industri pasti akan menggunakan teknologi maju diberbagai sektor kegiatan. Penerapan teknologi canggih tersebut di satu pihak memacu pembangunan ekonomi memasuki era industrialisasi, namun dipihak lain apabila tidak ditangani secara berencana dan terpadu, dapat meningkatkan kecelakaan kerja, penyakit akibat kerja, ergonomi bahkan peningkatan pengangguran (Barthos, 2009:139).

Dengan semakin berkembangnya teknologi dalam proses produksi, maka akan memberikan pengaruh yang besar terhadap tenaga kerja. Adanya teknologi yang disertai peralatan modern disamping membawa kemudahan dalam berproduksi juga memiliki tingkat risiko kecelakaan yang tinggi. Oleh karena itu diperlukan ketelitian dan kewaspadaan dalam mengoperasikan peralatan yang ada. Kesalahan di dalam penggunaan peralatan, kurangnya perlengkapan alat pelindung tenaga kerja, serta ketrampilan tenaga kerja yang kurang memadai ternyata dapat menimbulkan kemungkinan bahaya yang sangat besar yaitu kecelakaan kerja, kebakaran, peledakan, pencemaran lingkungan dan penyakit. Kecelakaan kerja akan menimbulkan hal-hal yang sangat negatif baik kerugian ekonomi maupun mengakibatkan penderitaan manusia atau tenaga kerja yang bersangkutan. Sedangkan lingkungan kerja yang tidak aman dan kurang sehat juga dapat mengganggu tenaga kerja dalam melaksanakan pekerjaannya.

Jika perusahaan dapat menurunkan tingkat dan beratnya kecelakaan kerja, penyakit dan hal-hal yang berkaitan dengan stress, serta mampu meningkatkan kualitas kehidupan kerja para pekerjanya, perusahaan akan semakin efektif. Peningkatan-peningkatan terhadap hal ini akan menghasilkan meningkatnya produktivitas karena menurunnya hari kerja yang hilang, meningkatnya efisiensi dan kualitas pekerja yang lebih berkomitmen, menurunnya biaya-biaya kesehatan dan asuransi, tingkat kompensasi pekerja dan pembayaran langsung yang lebih rendah karena menurunnya pengajuan klaim, fleksibilitas dan adaptabilitas yang besar sebagai akibat dari meningkatnya partisipasi dan rasa kepemilikan dan rasio seleksi tenaga kerja yang lebih baik karena meningkatnya citra perusahaan (Schuler, et.al., 2007:223).

Rumah Sakit sebagai institusi pelayanan kesehatan bagi masyarakat dengan karateristik tersendiri yang dipengaruhi oleh perkembangan ilmu pengetahuan kesehatan, kemajuan teknologi, dan kehidupan sosial ekonomi masyarakat harus mampu meningkatkan pelayanan yang lebih bermutu dan terjangkau oleh masyarakat agar terwujud derajat kesehatan yang setinggi-tingginya. Selain itu rumah sakit juga dituntut melaksanakan dan mengembangkan program K3 (Keselamatan dan Kesehatan Kerja) di rumah sakit (K3RS) seperti yang tercantum dalam buku Standar Pelayanan Rumah Sakit dan terdapat dalam instrumen akreditasi Rumah Sakit.

Pelaksanaan program keselamatan dan kesehatan kerja bagi karyawan di rumah sakit sangatlah penting karena bertujuan untuk menciptakan sistem keselamatan dan kesatuan kerja dengan melibatkan unsur manajemen, tenaga kerja, kondisi dan lingkungan kerja yang terintegrasi dalam rangka mengurangi kecelakaan. Kondisi yang demikian tentunya menuntut rumah sakit untuk mengedepankan perlindungan terhadap tenaga kerja yang dapat berpengaruh pada produktivitas kerja. Untuk mencapai produktivitas yang tinggi tidaklah mudah karena rumah sakit juga menghadapi kendala antara lain berhubungan dengan sumber daya manusia. Manusia adalah faktor yang penting dalam proses produksi karena sumber daya manusia merupakan aset yang penting dalam rumah sakit. Suatu proses produksi yang tidak lancar karena kecelakaan kerja akan mengakibatkan berkurangnya efisiensi. Penurunan produktivitas dapat terjadi karena mesin yang rusak, karyawan yang cidera dan sebagainya. Produktivitas akan optimal bila tenaga kerja selalu terjamin keselamatan dan kesehatan kerja.

Jaminan keselamatan dan kesehatan kerja yang tidak terpenuhi dalam perusahaan dapat mengakibatkan menurunnya produktivitas kerja karyawan, yang pada ujungnya akan pula menurunkan produktivitas perusahaan. Beberapa faktor yang mempengaruhi tingginya angka kecelakaan kerja serta penyakit akibat kerja, antara lain kurangnya pengetahuan karyawan tentang bahaya kecelakaan dan penyakit akibat kerja karena karyawan tidak diberi pengetahuan mengenai keselamatan dan kesehatan kerja, selain itu juga kurangnya perhatian dari pihak manajemen mengenai pentingnya perlindungan keselamatan dan kesehatan kerja bagi karyawan. Masalah tersebut mengindikasikan bahwa faktor keselamatan dan kesehatan kerja memiliki peranan yang penting dalam mempengaruhi produktivitas kerja karyawan. Keselamatan dan kesehatan kerja yang tidak terpenuhi dapat mempengaruhi produktivitas karyawan. Karyawan menjadi enggan bekerja karena takut akan terjadi kecelakaan kerja ataupun terkena penyakit akibat kerja, sehingga tentunya akan mengganggu kontinuitas perusahaan.

Saputra (2014) menyimpulkan bahwa keselamatan kerja memberikan pengaruh yang signifikan kepada produktivitas kerja karyawan. Penelitian ini didukung oleh Kaligis, et.al (2013) yang menyatakan bahwa keselamatan dan kesehatan kerja berpengaruh 
signifikan secara simultan terhadap produktivitas kerja. Akan tetapi secara parsial keselamatan dan kesehatan kerja tidak memberikan pengaruh yang signifikan terhadap produktivitas kerja. Hasil penelitian tersebut diperkuat oleh Ukhisia, et.al (2013) yang menyimpulkan bahwa secara parsial hanya kesehatan kerja yang memberikan pengaruh secara signifikan terhadap produktivitas kerja, sedangkan keselamatan kerja tidak memberikan pengaruh yang signifikan. Akan tetapi secara simultan, keselamatan dan kesehatan kerja memberikan pengaruh yang signifikan terhadap produktivitas kerja.

\section{Tujuan Penelitian}

Untuk mengetahui dan menganalisa :

1. Pengaruh secara parsial Keselamatan kerja karyawan terhadap produktivitas kerja karyawan

2. Pengaruh secara parsial Kesehatan kerja karyawan terhadap produktivitas kerja karyawan

3. Pengaruh secara simultan keselamatan dan kesehatan kerja terhadap produktivitas kerja karyawan.

\section{Hipotesis}

Sesuai dengan tujuan penelitian di atas, dapat dirumuskan hipotesis sebagai berikut:

$\begin{array}{rlrl}\mathrm{H}_{1}: & \begin{array}{l}\text { Keselamatan kerja secara parsial memiliki } \\ \text { pengaruh yang signifikan }\end{array} & \text { terhadap } \\ \text { produktivitas kerja karyawan } & \\ \mathrm{H}_{2}: & \begin{array}{l}\text { Kesehatan kerja secara parsial } \\ \text { pengaruh yemiliki }\end{array} & \begin{array}{c}\text { mang signifikan } \\ \text { produktivitas kerja karyawan }\end{array}\end{array}$

$\mathrm{H}_{3}$ : Keselamatan dan kesehatan kerja secara simultan memiliki pengaruh yang signifikan terhadap produktivitas kerja karyawan

\section{METODE PENELITIAN}

Jenis penelitian yang digunakan adalah penelitian kuantitatif, menurut Margono (2010:105) penelitian kuantitatif yaitu suatu proses menemukan pengetahuan yang menggunakan data berupa angka sebagai alat untuk menemukan keterangan mengenai apa yang ingin kita ketahui. Objek yang digunakan dalam penelitian ini adalah salah satu rumah sakit swasta di kota Bandung, sedangkan unit analisisnya adalah karyawan rumah sakit tersebut. Jumlah karyawan di rumah sakit swasta tersebut saat dilakukan penelitian tersebut adalah 1386 orang. Adapun teknik sampel yang digunakan dalam penelitian ini adalah simple random sampling (sampel acak sederhana), sehingga subyeknya yang ada didalam populasi di anggap sama. Dengan demikian, maka setiap subyek memperoleh kesempatan yang sama untuk dipilih menjadi sampel. Untuk memudahkan digunakanlah bantuan tabel
Isaac dan Michael dalam Sugiyono (2010:128), dengan taraf kesalahan 5\% didapatkan jumlah sampel untuk penelitian tersebut adalah 279 dibulatkan menjadi 280 orang. Variabel penelitian terdiri dari variabel indepeden yaitu Keselamatan Kerja $\left(\mathrm{X}_{1}\right)$ dan Kesehatan Kerja $\left(\mathrm{X}_{2}\right)$ serta variabel dependen yaitu Produktivitas Kerja (Y)

\section{Definisi Operasi dan Pengukuran Variabel}

1. Keselamatan kerja adalah segala macam upaya untuk mewujudkan keadaan atau kondisi yang aman dan selamat di lingkungan kerja baik secara fisik maupun sosial psikologis (Ridley, 2008:111), indikator-indikator keselamatan kerja yaitu :

\section{1) Lingkungan Kerja Secara Fisik}

a. Pemberian tanda peringatan

b. Kondisi peralatan perlindungan kerja

c. Ketersediaan peralatan perlindungan kerja

d. Ketersediaan peralatan pencegah kecelakaan kerja

e. Kondisi peralatan pencegah kecelakaan kerja

2) Lingkungan Sosial Psikologis
a. Aturan yang baku
b. Penanganan kecelakaan kerja
c. Tunjangan kecelakaan kerja

2. Kesehatan kerja adalah segala upaya yang diterapkan untuk meningkatkan kondisi kesehatan tenaga kerja dan melindungi tenaga kerja dari risiko penyakit akibat kerja”. Budiono (2009:7), indikator-indikator kesehatan kerja yaitu :

1) Kondisi Kerja
a. Kebersihan lingkungan
b. Penerangan tempat kerja
c. Suhu atau ventilasi
d. Sistem pengolahan limbah

2) Sarana Kesehatan
a. Penyediaan air bersih
b. Sarana kamar mandi
c. Tempat istirahat

3) Pemeliharaan Kesehatan
a. Pemberian makanan bergizi
b. Pelayanan kesehatan
c. Jaminan kesehatan 
3. Produktivitas Kerja adalah bagaimana menghasilkan atau meningkatkan hasil barang dan jasa setinggi mungkin dengan memanfaatkan sumber daya secara efisien.(Paul Mali, 2006:6), indikator-indikator produktivitas kerja yaitu :

1) Menggunakan waktu dengan efektif
a. Waktu kerja
b. Penyelesaian pekerjaan
c. Konsistensi penyelesaian pekerjaan
d. Bekerja dalam tekanan waktu

2) Memahami dan meminimalisasi kesalahan dalam bekerja
a. Pengetahuan tentang pekerjaan
b. Pelaksanakan pekerjaan
c. Bekerja secara mandiri
d. Penyelesaian masalah dalam pekerjaan

3) Hubungan antar pribadi
a. Bekerja dalam tim
b. Hubungan dengan rekan sejawat
c. Hubungan dengan atasan

4) Tingkat kehadiran

Absensi

Untuk mempermudah perhitungan, setiap pertanyaan dari kuesioner diberi nilai dengan skala Likert. Skala Likert merupakan metode yang mengukur sikap dengan menyatakan setuju atau ketidaksetujuannya terhadap subyek, objek, atau kejadian tertentu (Surakhmad, 2001:67). Skala Likert umumnya menggunakan lima angka penilaian yaitu, sangat setuju (skor 5), setuju (skor 4), kurang setuju (skor 3), tidak setuju (skor 2), sangat tidak setuju (skor 1).

\section{Pengujian Instrumen dan Analisis Data}

Dalam penelitian ini instrumen-instrumen yang ada dilakukan pengujian berupa uji validitas dan uji reliabilitas instrumen. Uji asumsi klasik dilakukan dengan uji normalitas data, uji autokorelasi, uji multikolonieritas dan uji heteroskedastisitas.

Untuk menguji hipotesis dalam penelitian ini digunakan model analisis jalur (path analysis) sebagai berikut:

$$
\mathrm{Y}=\rho \mathrm{yx}_{1} \mathrm{X}_{1}+\rho \mathrm{yx}_{2} \mathrm{X}_{2}+\varepsilon \quad \rightarrow(1)
$$

Keterangan :

$\mathrm{Y} \quad=$ Produktivitas kerja

$\rho \mathrm{yx}_{1}=$ Koefisien jalur yang menunjukkan pengaruh langsung dari varibel $\mathrm{X}_{1}$ kepada variabel Y

$$
\mathrm{X}_{1}=\text { Keselamatan kerja }
$$

$\rho \mathrm{yx}_{2}=$ Koefisien jalur yang menunjukkan pengaruh langsung dari varibel $\mathrm{X}_{2}$ kepada

variabel Y

$\mathrm{X}_{2}=$ Kesehatan kerja

$\varepsilon \quad=$ Variabel pengganggu

4. Uji t (Uji Parsial)

Uji t digunakan untuk mengetahui signifikan atau tidak pengaruh variabel independen terhadap variabel dependen secara parsial atau individual (sendiri-sendiri). Kriteria pengujiannya adalah dengan melihat nilai signifikasi, jika nilai Signifikansi $\leq 0,05$ artinya variabel independen berpengaruh signifikan terhadap variabel dependen.

\section{Uji F (Uji Simultan)}

Uji F dilakukan untuk menghitung koefisien jalur secara simultan. Untuk menguji tingkat signifikan tidaknya pengaruh variabel independen terhadap variabel dependen secara simultan. Kriterian pengujiannya adalah dengan melihat nilai signifikasi, Jika nilai Signifikansi $\leq 0,05$ artinya variabel independen secara simultan berpengaruh signifikan terhadap variabel dependen.

6. Koefisien Determinasi $\left(\mathrm{R}^{2}\right)$

Koefisien determinasi $\left(R^{2}\right)$ pada intinya mengukur seberapa jauh kemampuan model dalam menerangkan variasi variabel dependen. Nilai koefisien determinasi adalah antara nol dan satu. Nilai $R^{2}$ yang kecil berarti kemampuan variabel-variabel independen dalam menjelaskan variasi variabel dependen amat terbatas. Nilai yang mendekati satu berarti variabel-variabel independen memberikan hampir semua informasi yang dibutuhkan untuk memprediksi variasi variabel dependen.

Rangkaian analisa data di atas dilakukan penghitungan melalui program software SPSS for Windows versi 17 yang membantu menyelesaikan formulasi yang telah dijelaskan sebelumnya

\section{HASIL DAN PEMBAHASAN}

\section{Gambaran Responden}

Jumlah sampel yang digunakan dalam penelitian ini adalah sebanyak 280 orang. Gambaran karakteristik responden seperti tingkat pendidikan, bidang pekerjaan dan lamanya bekerja dijelaskan pada tabel berikut : 
Tabel 1 Responden Berdasarkan Pendidikan

\begin{tabular}{lll}
\hline Responden & Frekuensi & Prosentase \\
\hline SLTA & 89 & 31,8 \\
\hline Diploma3 & 163 & 58,2 \\
\hline S1 & 25 & 9,8 \\
\hline S2 & 2 & 0,7 \\
\hline S3 & 1 & 0,4 \\
\hline Jumlah & 280 & 100 \\
\hline
\end{tabular}

Sumber : RS. Swasta di kota Bandung, tahun 2019

Berdasarkan tabel 1 di atas diperoleh data, dari 280 responden, jumlah paling banyak adalah responden dengan pendidikan D3 yaitu sebanyak 163 orang atau $58,2 \%$, selanjutnya responden dengan pendidikan SLTA sebanyak 89 orang atau $31,8 \%$, responden dengan pendidikan S1 sebanyak 25 orang atau 9,8\%, responden dengan pendidikan S2 sebanyak 2 orang atau $0,7 \%$ dan responden dengan pendidikan S3 sebanyak 1 orang atau $0,4 \%$.

Tabel 2 Responden Berdasarkan Lamanya Bekerja

\begin{tabular}{lll}
\hline Responden & irekuensi & 'rosentase \\
\hline $0-5$ tahun & 6 & 0,7 \\
\hline $6-10$ tahun & 9 & 3,9 \\
\hline $11-15$ tahun & 3 & 8,9 \\
\hline $16-20$ tahun & 2 & 5,0 \\
\hline $21-25$ tahun & 4 & 2,1 \\
\hline $26-30$ tahun & 5 &, 4 \\
\hline $31-35$ tahun &. &, 9 \\
\hline$>35$ tahun & &, 1 \\
\hline Jumlah & 80 & 00 \\
\hline Sum
\end{tabular}

Sumber : RS. Swasta di kota Bandung, tahun 2019

Berdasarkan tabel 2 terlihat bahwa sebagian besar responden telah bekerja antara 0-5 tahun yaitu sebanyak 86 orang atau $30,7 \%$, kemudian antara 1115 tahun sebanyak 53 orang atau $18,9 \%$, antara 1620 tahun sebanyak 42 orang atau $15,0 \%$, antara $6-10$ tahun sebanyak 39 orang atau $13,9 \%$, antara $21-25$ tahun sebanyak 34 orang atau $12,1 \%$, antara $26-30$ tahun sebanyak 15 orang atau 5,4\% dan antara 31-35 tahun sebanyak 8 orang atau $2,9 \%$. Sedangkan sisanya sebanyak 3 orang atau $1,1 \%$ bekerja lebih dari 35 tahun.

Tabel 3 Responden Berdasarkan Bidang Pekerjaan

\begin{tabular}{lll}
\hline Responden & Frekuensi & Prosentase \\
\hline Keperawatan & 170 & 60,7 \\
\hline $\begin{array}{l}\text { Medis Non } \\
\text { Keperawatan }\end{array}$ & 30 & 10,7 \\
\hline Medis & 17 & 6,1 \\
\hline Umum & 63 & 22,5 \\
\hline Jumlah & 280 & 100 \\
\hline
\end{tabular}

Sumber : RS. Swasta di kota Bandung, tahun 2019

Berdasarkan tabel 3 terlihat bahwa sebagian besar responden bekerja dibidang keperawatan yaitu sebanyak 170 orang atau $60,7 \%$, kemudian bekerja di bidang umum sebanyak 63 orang atau 11,5\%, bekerja di bidang medis non keperawatan sebanyak 30 orang atau $10,7 \%$, dan 17 orang atau $6,1 \%$ bekerja di bidang medis.

\section{Uji Instrumen Penelitian}

\section{Uji Validitas}

Menurut Ghozali (2013:53) uji validitas dilakukan dengan membandingkan nilai $r$ hitung (untuk setiap butir dapat dilihat pada kolom corrected item-total correlations) dengan $r$ tabel untuk degree of freedom $(d f)=\mathrm{n}-\mathrm{k}$, dalam hal ini $\mathrm{n}$ adalah jumlah sampel dan $\mathrm{k}$ adalah jumlah variabel independen. Dengan Hasil pengujian validitas terhadap variabel-variabel penelitian adalah sebagai berikut :

Tabel 4 Hasil Pengujian Validitas Instrumen Variabel Keselamatan Kerja $\left(\mathrm{X}_{1}\right)$

\begin{tabular}{|c|c|c|c|c|c|}
\hline Dimensi & $\begin{array}{l}\text { Kode } \\
\text { Butir }\end{array}$ & $\begin{array}{c}\text { Koefisen } \\
\text { korelasi dengan } \\
\text { skor total } \mathrm{X}_{1}\end{array}$ & $\begin{array}{c}r_{\text {tabel }} \\
(\alpha=5 \%)\end{array}$ & $\begin{array}{l}\text { Signifikan/ } \\
\text { Non } \\
\text { signifikan }\end{array}$ & Kesimpulan \\
\hline Lingkungan & $\mathrm{X} 1.1$ & $0,819^{* * *}$ & 0,113 & Signifikan & Valid \\
\hline \multirow{4}{*}{$\begin{array}{l}\text { kerja secara } \\
\text { fisik }\end{array}$} & $\mathrm{X} 1.2$ & $0,863^{\text {** }}$ & 0,113 & Signifikan & Valid \\
\hline & $\mathrm{X} 1.3$ & $0,862^{\text {*** }}$ & 0,113 & Signifikan & Valid \\
\hline & $\mathrm{X} 1.4$ & $0,862^{* *}$ & 0,113 & Signifikan & Valid \\
\hline & $\mathrm{X} 1.5$ & 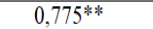 & 0,113 & Signifikan & Valid \\
\hline \multirow{3}{*}{$\begin{array}{l}\text { Lingkungan } \\
\text { sosial } \\
\text { psikologis }\end{array}$} & $\mathrm{X} 1.6$ & $0,745^{\text {*** }}$ & 0,113 & Signifikan & Valid \\
\hline & $\mathrm{X} 1.7$ & $0,747^{\text {*k }}$ & 0,113 & Signifikan & Valid \\
\hline & $\mathrm{X} 1.8$ & $0,388^{* * *}$ & 0,113 & Signifikan & Valid \\
\hline
\end{tabular}

Tabel 5 Hasil Pengujian Validitas Instrumen Variabel Kesehatan Kerja $\left(X_{2}\right)$

\begin{tabular}{|c|c|c|c|c|c|}
\hline Dimensi & $\begin{array}{l}\text { Kode } \\
\text { Butir }\end{array}$ & $\begin{array}{c}\text { Koefisen } \\
\text { korelasi } \\
\text { dengan skor } \\
\text { total } \mathrm{X}_{2}\end{array}$ & $\begin{array}{c}r_{\text {tabel }} \\
(\alpha=5 \%)\end{array}$ & $\begin{array}{l}\text { Signifikan/ } \\
\text { Non } \\
\text { signifikan }\end{array}$ & Kesimpulan \\
\hline \multirow[t]{4}{*}{ Kondisi kerja } & X2.9 & $0,347^{* * * *}$ & 0,113 & Signifikan & Valid \\
\hline & $\mathrm{X} 2.10$ & $0,542^{\text {**** }}$ & 0,113 & Signifikan & Valid \\
\hline & $\mathrm{X} 2.11$ & $0.691^{\text {*** }}$ & 0,113 & Signifikan & Valid \\
\hline & $\mathrm{X} 2.12$ & $0,748^{\text {*** }}$ & 0,113 & Signifikan & Valid \\
\hline \multirow{3}{*}{$\begin{array}{c}\text { Sarana } \\
\text { kesehatan }\end{array}$} & $\mathrm{X} 2.13$ & $0,638^{\text {**** }}$ & 0,113 & Signifikan & Valid \\
\hline & $\mathrm{X} 2.14$ & $0,503^{\text {**** }}$ & 0,113 & Signifikan & Valid \\
\hline & $\mathrm{X} 2.15$ & $0,687^{\text {*** }}$ & 0,113 & Signifikan & Valid \\
\hline \multirow{3}{*}{$\begin{array}{c}\text { Jaminan } \\
\text { kesehatan }\end{array}$} & $\mathrm{X} 2.16$ & $0,676^{\text {** }}$ & 0,113 & Signifikan & Valid \\
\hline & $\mathrm{X} 2.17$ & 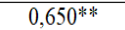 & 0,113 & Signifikan & Valid \\
\hline & $\mathrm{X} 2.18$ & $0,700^{* * *}$ & 0,113 & Signifikan & Valid \\
\hline
\end{tabular}

Sumber : Data yang telah diolah (output SPSS 17.0), tahun 2019

Tabel 6 Hasil Pengujian Validitas Instrumen Variabel Produktivitas Kerja (Y)

\begin{tabular}{|c|c|c|c|c|c|}
\hline Dimensi & $\begin{array}{l}\text { Kode } \\
\text { Butir }\end{array}$ & $\begin{array}{l}\text { Koefisen korelasi } \\
\text { dengan skor total Y }\end{array}$ & $\begin{array}{c}r_{\text {tabel }} \\
(\alpha=5 \%)\end{array}$ & $\begin{array}{l}\text { Signifikan/ } \\
\text { Non } \\
\text { signifikan }\end{array}$ & Kesimpulan \\
\hline \multirow{4}{*}{$\begin{array}{l}\text { Menggunakan } \\
\text { waktu dengan } \\
\text { efektif }\end{array}$} & Y19 & $0,738^{* *}$ & 0,113 & Signifikan & Valid \\
\hline & Y20 & $0,850^{* *}$ & 0,113 & Signifikan & Valid \\
\hline & Y21 & $0,887^{* * *}$ & 0,113 & Signifikan & Valid \\
\hline & Y22 & $0,873^{* * *}$ & 0,113 & Signifikan & Valid \\
\hline \multirow{4}{*}{$\begin{array}{l}\text { Memahami dan } \\
\text { meminimalisasi } \\
\text { kesalahan } \\
\text { dalam bekerja }\end{array}$} & Y23 & $0,906^{* * *}$ & 0,113 & Signifikan & Valid \\
\hline & $\mathrm{X} 24$ & $0,926^{* * *}$ & 0,113 & Signifikan & Valid \\
\hline & $\mathrm{X} 25$ & $0,900^{* * *}$ & 0,113 & Signifikan & Valid \\
\hline & Y26 & $0,918^{* *}$ & 0,113 & Signifikan & Valid \\
\hline \multirow{3}{*}{$\begin{array}{l}\text { Hubungan antar } \\
\text { pribadi }\end{array}$} & Y27 & $0,894^{* *}$ & 0,113 & Signifikan & Valid \\
\hline & Y28 & $0,866^{* * *}$ & 0,113 & Signifikan & Valid \\
\hline & Y29 & $0,849^{* * *}$ & 0,113 & Signifikan & Valid \\
\hline $\begin{array}{l}\text { Tingkat } \\
\text { kehadiran }\end{array}$ & Y30 & $0,840^{* *}$ & 0,113 & Signifikan & Valid \\
\hline
\end{tabular}


Dengan menggunakan $r_{\text {tabel }}$, maka nilai $r_{\text {tabel }}$ pada $\mathrm{n}=280$, didapatkan nilai $\alpha=0,01$ sebesar 0,148 dan $\alpha=0,05$ sebesar 0,113. Kevalidan masing-masing instrumen tersebut ditentukan oleh besarnya nilai koefisien korelasi $\left(r_{\text {hitung }}\right)$ yang diperoleh ternyata lebih besar dari nilai $r_{\text {tabel }}$ dengan tingkat signifikansi 0,05 yang nilainya adalah 0,113 . Oleh karena itu semua item variabel dalam penelitian tersebut dapat digunakan untuk menguji hipotesis tanpa ada yang dihilangkan atau diganti.

\section{Uji Reliabilitas}

Pengujian realibilitas instrumen dilakukan dengan menggunakan Alfa Cronbach. Pengujian realibilitas variabel keselamatan kerja $\left(\mathbf{X}_{\mathbf{1}}\right)$, kesehatan kerja $\left(\mathbf{X}_{\mathbf{2}}\right)$ dan produktivitas kerja (Y) adalah sebagai berikut :

Tabel 7 Hasil Pengujian Realibilitas untuk Masing-Masing Variabel Penelitian

\begin{tabular}{lccc}
\hline \multicolumn{1}{c}{ Variabel } & $\alpha$ cronbach's & Kategori & Kesimpulan \\
\hline Keselamatan Kerja $\left(X_{1}\right)$ & 0,894 & Layak & Reliabel \\
\hline Kesehatan Kerja $\left(X_{2}\right)$ & 0,821 & Layak & Reliabel \\
\hline Produktivitas Kerja $(Y)$ & 0,970 & Layak & Reliabel \\
\hline
\end{tabular}

Sumber : Data yang telah diolah (output SPSS 17.0), tahun 2019

Dengan melihat tabel $7 \mathrm{di}$ atas maka didapatkan bahwa secara keseluruhan uji konsistensi dan keandalan atas skor jawaban instrumen untuk masing-masing variabel disimpulkan reliabel karena memiliki cronbach's alpha $\propto>60 \%(0,60)$.

\section{Uji Asumsi Klasik}

Uji ini dimaksudkan untuk membuktikan bahwa model regresi penelitian telah memenuhi asumsi klasik, tidak terdapat masalah-masalah regresi yang tidak diperbolehkan dalam pengolahan data regresi secara statistik (Ghozali, 2013:105).

\section{Uji Normalitas}

Uji normalitas bertujuan untuk menguji apakah dalam model regresi, variabel penggangu atau residual memiliki distribusi normal (Ghozali, 2013:160). Untuk menguji apakah residual berdistribusi normal atau tidak dengan cara analisis statistik non-parametrik One-Sample KolmogorovSmirnov (Uji K-S).

Berdasarkan uji One-Sample Kolmogorov-Smirnov, menunjukkan besarnya nilai signifikansi adalah 0,512 yang berarti $>0,05$, hal ini berarti $\mathrm{H}_{0}$ diterima yang mengindikasikan data residual terdistribusi normal, sehingga dapat disimpulkan bahwa model regresi memenuhi asumsi normalitas.

\section{Uji Autokorelasi}

Cara yang digunakan untuk mendeteksi ada atau tidaknya autokorelasi dengan menggunakan Run Test. Berdasarkan uji Runs Test, menunjukkan besarnya nilai signifikansi adalah 0,139 yang berarti $>0,05$, hal ini berarti $\mathrm{H}_{0}$ diterima yang mengindikasikan bahwa tidak terdapat autokorelasi antar nilai residual. Sehingga dapat disimpulkan bahwa model regresi memenuhi asumsi autokorelasi.

\section{Uji Multikolinearitas}

Uji multikolinearitas adalah untuk menganalisa adanya hubungan linear antara beberapa atau semua variabel yang menjelaskan (variabel bebas) dalam model regresi. Jika model terdapat multikolinearitas maka model tersebut memiliki kesalahan standar yang besar sehingga koefisien tidak dapat ditaksir dengan ketepatan yang tinggi.

Hasil perhitungan nilai tolerance menunjukkan tidak ada variabel independen yang memiliki nilai tolerance kurang dari 0,10 . Hasil perhitungan nilai VIF juga menunjukkan hal yang sama tidak ada satu variabel independen yang memiliki nilai VIF lebih dari 10. Sehingga dapat disimpulkan bahwa pada model regresi tidak terjadi gejala multikolonieritas antar variabel independen.

\section{Uji Heteroskedastisitas}

Heteroskedastisitas terjadi jika gangguan muncul dalam fungsi regresi yang mempunyai varian yang tidak sama sehingga penaksir OLS tidak efisien baik dalam sampel kecil maupun besar. Salah metode yang digunakan adalah Uji Glejser yaitu dengan meregresi absolut residual dengan variabel independen.

Berdasarkan hasil Uji Glejser, menunjukkan bahwa seluruh variabel independen memiliki nilai signifikansi $>0,05$ sehingga dapat disimpulkan bahwa model regresi yang ada terbebas dari asumsi heteroskedastisitas.

\section{Analisis Jalur (Path Analysis)}

Pada pengujian masing-masing hipotesis, digunakan model analisis jalur (Path Analysis). Akan tetapi sebelumnya dibahas dahulu mengenai ada tidaknya hubungan antara masing-masing variabel yang diteliti melalui uji korelasional. Hal tersebut perlu dan menjadi dasar penggunaan regresi ataupun analisis jalur. Berdasarkan pengujian, ditemukan koefisien korelasi antar variabel sebagai berikut :

Tabel 8 Matriks Korelasi Antar Variabel

\begin{tabular}{lccc}
\hline Variabel & $\begin{array}{c}\text { Keselamatan Kerja } \\
\left(\mathrm{X}_{1}\right)\end{array}$ & $\begin{array}{c}\text { Kesehatan Kerja } \\
\left(\mathrm{X}_{2}\right)\end{array}$ & $\begin{array}{c}\text { Produktivitas } \\
\text { Kerja }(\mathrm{Y})\end{array}$ \\
\hline Keselamatan Kerja $\left(\mathrm{X}_{1}\right)$ & 1,00 & 0,521 & 0,653 \\
\hline Kesehatan Kerja $\left(\mathrm{X}_{2}\right)$ & 0,521 & 1,00 & 0,557 \\
\hline Produktivitas Kerja $(\mathrm{Y})$ & 0,653 & 0,557 & 1,00 \\
\hline Sumber : Hasil pengolahan data primer, tahun 2019 & &
\end{tabular}

Dengan hasil pengujian di atas, dapat disimpulkan bahwa kedua variabel yang diteliti masing-masing memiliki korelasi yang positif berdasarkan arah koefisien yang ditemukan. Hal ini mengindikasikan 
semakin perlunya dilanjutkan pengujian ke tingkat analisis jalur.

Selanjutnya model persamaan yang diajukan untuk pengujian pengaruh keselamatan dan kesehatan kerja terhadap produktivitas kerja di rumah sakit tersebut adalah sebagai berikut

$\mathrm{Y}=\rho \mathrm{y} x_{1} \mathrm{X}_{1}+\rho \mathrm{y} x_{2} \mathrm{X}_{2}+\varepsilon \quad \rightarrow(2)$

dimana:

$\mathrm{Y}=$ Menyatakan variabel produktivitas kerja

$\rho x_{1}=$ Koefisien jalur yang menunjukkan pengaruh langsung dari varibel

\section{$\mathrm{X}_{1}$ kepada variabel $\mathrm{Y}$}

py $x_{2}=$ Koefisien jalur yang menunjukkan pengaruh langsung dari varibel

$$
\mathrm{X}_{2} \text { kepada variabel } \mathrm{Y}
$$

$X_{1}=$ Menyatakan variabel keselamatan kerja

$X_{2}=$ Menyatakan variabel kesehatan kerja

$\varepsilon=\operatorname{variabel}$ pengganggu (Epsilon)

Berdasarkan pengujian menggunakan bantuan program SPSS versi 17, diperoleh hasil sebagai berikut :

\section{Tabel 9 Hasil Pengujian Hipotesis}

\begin{tabular}{llcccc}
\multicolumn{5}{c}{ Model Summary $^{\mathrm{b}}$} \\
\hline Model & $\mathrm{R}$ & R Square & $\begin{array}{c}\text { Adjusted R } \\
\text { Square }\end{array}$ & $\begin{array}{c}\text { Std. Error of the } \\
\text { Estimate }\end{array}$ \\
\hline 1 & $.701^{\mathrm{a}}$ & .491 & .487 & 6.8949634 \\
\hline
\end{tabular}

Tabel 10 Hasil Pengujian Hipotesis

\begin{tabular}{|c|c|c|c|c|c|c|}
\hline \multicolumn{7}{|c|}{ Coefficients $^{\mathrm{a}}$} \\
\hline & & Unstandardized & Coefficients & $\begin{array}{l}\text { Standardized } \\
\text { Coefficients }\end{array}$ & & \\
\hline \multicolumn{2}{|l|}{ Model } & B & Std. Error & Beta & t & Sig. \\
\hline \multirow[t]{3}{*}{1} & (Constant) & 4.659 & 2.089 & & 2.230 & .027 \\
\hline & Keselamatan & .846 & .085 & .497 & 9.904 & .000 \\
\hline & Kesehatan & .516 & .087 & .298 & 5.934 & .000 \\
\hline
\end{tabular}

Karena menggunakan path analysis, maka variabel konstanta (constant) tidak diperhitungkan lagi. Sehingga koefisien yang dipergunakan adalah koefisien terstandarisasi (standardized Coefficients), berdasarkan tabel 10 maka persamaan struktural yang terbentuk adalah sebagai berikut :

$$
\mathrm{Y}=\mathbf{0 , 4 9 7} \mathrm{X}_{1}+\mathbf{0 , 2 9 8} \mathrm{X}_{2}+\boldsymbol{\varepsilon} \quad \rightarrow \text { (3) }
$$

Besarnya pengaruh variabel eksogen secara simultan terhadap variabel endogen (Y) ditunjukkan oleh besar kecilnya nilai koefisien determinasi multiple $\mathrm{R}^{2}$. Berdasarkan hasil penghitungan di atas, maka nilai koefisien determinasi atau $\mathrm{R}$-square $\left(\mathrm{R}^{2}\right)$ adalah sebesar 0,491. Sedangkan penetapan besarnya variabel epsilon $(\varepsilon)$ atau variabel pengganggu didapatkan dari rumus $1-\mathrm{R}^{2}$ yaitu sebesar 0,509 . Selanjutnya dari persamaan struktural yang terbentuk, dihasilkan struktur analisis jalur tentang pengaruh keselamatan dan kesehatan kerja terhadap produktivitas kerja karyawan di rumah sakit tersebut adalah sebagai berikut :

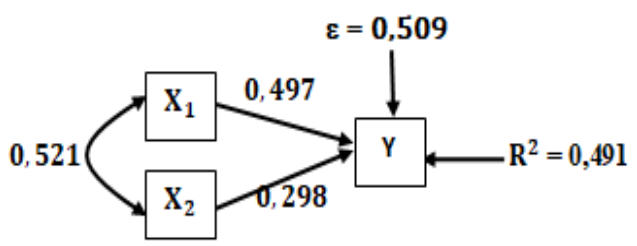

Gambar 1 Diagram Jalur Hasil Penelitian

\section{Uji T (Uji Parsial)}

Untuk mengetahui signifikan atau tidaknya pengaruh keselamatan kerja $\left(\mathrm{X}_{1}\right)$, kesehatan kerja $\left(\mathrm{X}_{2}\right)$ terhadap produktivitas kerja (Y), maka digunakan angka $\mathrm{t}_{\text {hitung. }}$. Nilai $\mathrm{t}_{\text {hitung }}$ seperti yang ditunjukkan pada tabel 10 keselamatan kerja $\left(\mathrm{X}_{1}\right)$ adalah sebesar 9,904 dan kesehatan kerja $\left(\mathrm{X}_{2}\right)$ adalah sebesar 5,934. Pengujian hipotesisnya dirumuskan sebagai berikut :

1. $\mathrm{H}_{\mathrm{a}}: \rho \mathrm{y} x_{1} \neq 0$ artinya, ada pengaruh yang signifikan dari keselamatan kerja dan kesehatan kerja terhadap produktivitas kerja.

2. $\mathrm{H}_{0}: \rho \mathrm{y} x_{1}=0$ artinya, tidak ada pengaruh yang signifikan dari keselamatan kerja dan kesehatan terhadap produktivitas kerja.

Adapun Kriteria pengujiannya adalah membandingkan $t_{\text {hitung }}$ dengan $t_{\text {tabel }}$. $t_{\text {tabel }}$ yang diperoleh pada derajat bebas (df) N-2 (280-2=278) dan diuji dua sisi (two tails test), maka didapatkan bahwa besarnya $t_{\text {tabel }}$ pada tingkat signifikansi $1 \%$ atau $\alpha=0,01$ adalah sebesar 2,601 dan pada tingkat signifikansi $5 \%$ atau $\alpha=0,05$ adalah sebesar 1,972 . Dengan demikian $\mathrm{t}_{\text {hitung }}$ sebesar 9,904 $>\mathrm{t}_{\text {tabel }}$ baik pada tingkat signifikansi $1 \%$ maupun $5 \%$, sehingga kesimpulannya $\mathrm{H}_{0}$ ditolak sebaliknya $\mathrm{H}_{\mathrm{a}}$ diterima yang berarti bahwa keselamatan kerja secara parsial berpengaruh terhadap produktivitas kerja karyawan di rumah sakit tersebut. Sedangkan untuk kesehatan kerja $t_{\text {hitung }}$ sebesar 5,934 $>\mathrm{t}_{\text {tabel }}$ baik pada tingkat signifikansi $1 \%$ maupun $5 \%$, sehingga kesimpulannya $\mathrm{H}_{0}$ ditolak sebaliknya $\mathrm{H}_{\mathrm{a}}$ diterima yang berarti bahwa kesehatan kerja secara parsial berpengaruh terhadap produktivitas kerja karyawan di rumah sakit tersebut.

\section{Uji F}

Berdasarkan tabel 11 besarnya pengaruh simultan tersebut dapat dilihat dari besarnya $\mathrm{R}$-square atau $\mathrm{R}^{2}$ yaitu sebesar 0,491. Untuk mengetahui signifikan atau tidaknya pengaruh keselamatan kerja $\left(\mathrm{X}_{2}\right)$ dan kesehatan kerja $\left(\mathrm{X}_{2}\right)$ secara simultan terhadap produktivitas kerja (Y), maka digunakan angka 
$\mathrm{f}_{\text {hitung. Nilai }} \mathrm{f}_{\text {hitung }}$ dapat dilihat melalui tabel berikut ini:

\section{Tabel 11 Hasil Pengujian Pengaruh Simultan}

\begin{tabular}{|c|c|c|c|c|c|c|}
\hline \multicolumn{7}{|c|}{ ANOVA ${ }^{b}$} \\
\hline Model & & Sum of Squares & df & Mean Square & F & Sig. \\
\hline 1 & Regression & 12700.204 & 2 & 6350.102 & 133.572 & $.000^{2}$ \\
\hline & Residual & 13168.724 & 277 & 47.541 & & \\
\hline & Total & 25868.929 & 279 & & & \\
\hline
\end{tabular}

Sumber : Hasil pengolahan data primer, tahun 2019

Seperti yang ditunjukkan pada tabel di atas didapatkan $\mathrm{f}_{\text {hitung }}$ sebesar 133,572. Pengujian hipotesisnya dirumuskan sebagai berikut :

1. $\mathrm{H}_{\mathrm{a}}: \rho y x_{1}=\rho \mathrm{y} x_{2} \neq 0$ artinya, ada pengaruh yang signifikan dari variabel independen terhadap variabel dependen

2. $\mathrm{H}_{0}: \rho y x_{1}=\rho y x_{2}=0$ artinya, tidak ada pengaruh yang signifikan dari variabel independen terhadap variabel dependen

Adapun Kriteria pengujiannya adalah membandingkan $\mathrm{f}_{\text {hitung dengan }} \mathrm{f}_{\text {tabel }}$. $\mathrm{f}_{\text {hitung }}$ berdasarkan tabel 15 adalah sebesar 133,572 sedangkan $\mathrm{f}_{\text {tabel }}$ yang diperoleh pada derajat bebas (df) untuk penyebut $=\mathrm{N}-\mathrm{k}-1(280-2-1=277)$ dan $\mathrm{df}$ pembilang $=\mathrm{k}$, maka didapatkan bahwa besarnya $\mathrm{f}_{\text {tabel }}$ pada tingkat signifikansi $1 \%$ atau $\alpha=0,01$ adalah sebesar 4,610 dan pada tingkat signifikansi 5 $\%$ atau $\alpha=0,05$ adalah sebesar 3,00. Dengan demikian $\mathrm{f}_{\text {hitung }}$ sebesar 133,572 $>\mathrm{f}_{\text {tabel }}$ baik pada tingkat signifikansi $1 \%$ maupun 5\%, sehingga kesimpulannya $\mathrm{H}_{0}$ ditolak sebaliknya $\mathrm{H}_{\mathrm{a}}$ diterima yang berarti bahwa keselamatan dan kesehatan kerja secara simultan berpengaruh terhadap produktivitas kerja karyawan di rumah sakit tersebut.

\section{Koefisien Determinasi $\left(\mathbf{R}^{2}\right)$}

Besarnya nilai koefisien determinasi atau R-square $\left(\mathrm{R}^{2}\right)$ berdasarkan tabel 13 adalah sebesar 0,491 . Berarti kontribusi variabel keselamatan kerja $\left(\mathrm{X}_{1}\right)$ dan keselamatan kerja $\left(\mathrm{X}_{2}\right)$ secara simultan terhadap produktivitas kerja (Y) adalah sebesar 49,1\%. Sedangkan variabel lain adalah sebesar 0,509, yang berarti 50,9\% dipengaruhi oleh variabel lain di luar model penelitian.

\section{SIMPULAN}

Pengaruh keselamatan dan kesehatan kerja terhadap produktivitas kerja karyawan di salah satu rumah sakit swasta di kota Bandung dapat disimpulkan sebagai berikut:

a. Keselamatan kerja secara parsial mempunyai pengaruh yang signifikan terhadap produktivitas kerja. Besarnya pengaruh Keselamatan kerja secara parsial terhadap produktivitas kerja adalah sebesar 0,497 atau 49,7\%.

b. Kesehatan kerja secara parsial mempunyai pengaruh yang signifikan terhadap produktivitas kerja. Besarnya pengaruh Kesehatan kerja secara parsial terhadap produktivitas kerja adalah sebesar 0,298 atau $29,8 \%$.

c. Secara simultan keselamatan kerja dan kesehatan kerja mempunyai pengaruh yang signifikan terhadap produktivitas kerja. Besar kontribusi secara simultan dari kedua variabel tersebut adalah sebesar 0,491 atau 49,1\%, sedangkan sisanya sebesar 0,509 atau 50,9\% dipengaruhi oleh variabel lain yang tidak dipakai atau diteliti dalam penelitian ini.

\section{DAFTAR PUSTAKA}

Albertus Heriyanto, et.al., 2006., Panduan Penelitian, Prestasi Pustaka, Jakarta.

Andri Saputra, 2014., Pengaruh keselamatan kerja terhadap produktivitas kerja karyawan di PT. Buran Nusa Respati, Kecamatan Anggana, Kabupaten Kutai Kartanegara, eJournal Ilmu Pemerintahan, 2014, 2 (3) : 3059-3069

Anto Dajan, 2008., Pengantar Metode Statistik, Jilid 1, Pustaka LP3ES, Jakarta

Ardana, et. al., 2012., Manajemen Sumber Daya Manusia, Edisi Pertama, Graha Ilmu, Yogyakarta.

Arfida, BR., 2003., Ekonomi Sumber Daya Manusia, Ghalia Indonesia, Jakarta

Arikunto, S., 2002., Prosedur Penelitian : Suatu Pendekatan Praktek, Edisi Revisi, Rineka Cipta, Jakarta.

Bashir Barthos, 2009., Manajemen Sumber Daya Manusia Suatu Pendekatan Makro, Bumi Aksara, Jakarta.

Bateman S. Thomas., et.al., 2004., Management Competing in the New Era, Fifth Edition, McGraw-Hill, New York.

Bella Gloria Ukhisia, dkk., 2013., Analisis Pengaruh Keselamatan dan Kesehatan Kerja Terhadap Produktivitas Karyawan dengan Metode Partial Least Squares, Jurnal Teknologi Pertanian Vol. 14 No. 2 [Agustus 2013] 95-104

Benet NB. Silalahi dan Rumondang B. Silalahi, 2000., Manajemen Keselamatan dan Kesehatan Kerja, PT Pustaka Binaman Pressindo, Jakarta

Bohlander, George., et.al., 2004., Managing Human Resources, $13^{\text {th }}$ Edition, South-Western Thomson, USA. 
Byars, Lloyd., et.al., 2006., Human Resource Management, $8^{\text {th }}$ Edition, McGraw-Hill, New York.

Dangur Konradus, 2006., Keselamatan dan Kesehatan Kerja, Penebar Swadaya, Jakarta

Dessler, Gary, 2010., Manajemen Sumber Daya Manusia, Jilid 1, Edisi Kesepuluh, PT. Indeks, Jakarta.

2010., Manajemen Sumber Daya Manusia, Jilid 2, Edisi Kesepuluh, PT. Indeks, Jakarta.

Edy Sutrisno, 2009., Manajemen Sumber Daya Manusia. Edisi Pertama, Cetakan Ketiga, Kencana, Jakarta.

Gujarati, Damodar N., 2003., Basic Econometrics, Fourth Edition, Mc.Graw Hill, New York.

Harun Al-Rasyid, 2001., Statistika Sosial, PPs Universitas Padjajaran, Bandung.

Heidjrachman Ranupandojo, et. al., 2002., Manajemen Personalia, Jilid 1, Bagian Penerbitan Fakultas Ekonomi, Universitas Gadjahmada, Yogyakarta.

Helena Poerwanto, et.al., 2005., Hukum Perburuhan Bidang Kesehatan dan Keselamatan Kerja, Badan Penerbit Fakultas Hukum Universitas Indonesia, Jakarta.

Husein Umar, 2005., Riset Sumber Daya Manusia Dalam Organisasi, Edisi Revisi, PT. Gramedia Pustaka Utama, Jakarta.

Imam Ghozali, 2005., Aplikasi Analisis Multivariate dengan Program SPSS, Badan Penerbit Universitas Diponegoro, Semarang.

International Labour Office, 2006., Penelitian Kerja \& Pengukuran Kerja, terjemahan J.L. Wetik , Erlangga, Jakarta.

John Soeprihanto, 2000., Manajemen Personalia, BPFE, Yogyakarta.

Kusriyanto, 2000., Meningkatkan Produktivitas Karyawan, LPPM, Jakarta.

M. Iqbal Hasan, 2002., Pokok-pokok Materi Metodologi Penelitian dan Aplikasinya, Ghalia Indonesia, Jakarta.

Mali, Paul., 2006., Understanding Productivity, Terjemahan J.M. Putti, Federal Publication Pte Ltd, Singapore.

Manullang, 2002., Pokok-pokok Hukum Keternagakerjaan Indonesia, PT Rineka Cipta, Jakarta.

Margono, S., 2010., Metode Penelitian Pendidikan, Rineka Cipta, Jakarta.
Masri Singarimbun, et.al., 2011., Metode Penelitian Survai, Edisi revisi, LP3ES, Jakarta.

Mathis, Robert L., et. al., 2002., Manajemen Sumber Daya Manusia, Salemba Empat, Jakarta

Mondy, R. Wayne, et. al., 2005., Human Resource Management, Ninth Edition, Prentice Hall, USA.

Muchdarsyah Sinungan, 2003., Produktivitas Apa dan Bagaimana, Bumi Aksara, Jakarta.

Noe, Raymond A., et. al., 2008., Human Resource Management : Gaining a competitive advantage, Fourth Edition, McGraw-Hill, New York.

Prabu Anwar Mangkunegara, 2010., Manajemen Sumber Daya Manusia Perusahaan, PT. Remaja Rosdakarya, Bandung.

Putra J. Ravianto, 2003., Produktivitas dan Pengukuran, Seri Produktivitas VIII, Lembaga Sarana Informasi Usaha dan Produktivitas, Jakarta.

Raldo Septian Victor Kaligis, dkk., 2013., Pengaruh Implementasi Program Keselamatan dan Kesehatan Kerja (K3) terhadap Produktivitas Kerja, Jurnal Sipil Statik Vol.1 No.3, Februari $2013(219-225) 219$

Ridley, John., 2008., Kesehatan dan Keselamatan Kerja : Ikhtisar, Edisi Ketiga, Erlangga, Jakarta.

Riduwan, et. al., 2013., Cara Menggunakan dan Memaknai Path Analysis, Cetakan kelima, Alfabeta, Bandung.

Schuler, Randall S., et. al., 2007., Manajemen Sumber Daya Manusia : Menghadapi Abad ke21, jilid 2 edisi 6, Erlangga, Jakarta.

Sedarmayanti, 2009., Sumber Daya Manusia dan Produktivitas Kerja, Mandar Maju, Bandung.

Sugeng Budiono, A.M., 2009., Bunga Rampai Higiene Perusahaan Ergonomi Kesehatan Kerja, Keselamatan Kerja, Badan Penerbit Universitas Diponegoro, Semarang.

Sugiyono, 2008., Metode Penelitian Kuantitatif, Kualitatif dan R\&D, Alfabeta, Bandung.

Suma'mur, 2009., Higiene Perusahaan dan Kesehatan Kerja (HIPERKES), Sagung Seto, Jakarta.

Taufik Tardianto, 2008., Suplemen Himpunan Peraturan Perundang-Undangan Keselamatan dan Kesehatan Kerja, BP. Panca Bhakti, Jakarta.

Tjutju Yuniarsih, 2009. Manajemen Sumber Daya Manusia, CV. Alfabeta, Bandung.

Uma Sekaran, 2006., Metodologi Penelitian Untuk Bisnis, Salemba Empat, Jakarta. 
206 Coopetition, Vol XI, Nomor 3, Nopember 2020, 197 - 206 (E-ISSN : 2615-4978, P-ISSN : 2086-4620)

Umi Narimawati, 2007., Riset Manajemen Sumber

Daya Manusia: Aplikasi Contoh dan Perhitungannya, Agung Media, Jakarta. 